\title{
Koneksi Politik Memperkuat Good Corporate Governance Terhadap Penghindaran Pajak
}

\author{
Suwandi \\ Universitas Muhammadiyah Gresik \\ suwandi@umg.ac.id
}

\begin{abstract}
The purpose of this study was to examine the influence of the interaction of political connections with Good Corporate Gavernance (GCG) on tax avoidance. The samples in this study were all manufacturing companies on the Indonesia Stock Exchange (BEI). The method of determining the sample using purposive sampling in accordance with predetermined criteria and obtained a sample of 279. The analysis technique is multiple linear regression. The test results of multiple linear regression analysis show that GCG has no effect on tax avoidance, while the interaction of political connections with Good Corporate Gavernance (GCG) has a significant effect on tax avoidance, so Good Corporate Gavernance (GCG) is proxied by the board of commissioners and audit committee purely moderating while the board of directors is a pseudo variable or quasi moderating. Tax avoidance is an effort to ease the tax burden by not violating the law. Tax avoidance is a complex and unique issue because it does not violate the law (legal) but is unwanted by the government because it reduces state revenue.
\end{abstract}

Keywords: Good Corporate Governance, Political Connections, Tax Avoidance

\begin{abstract}
Abstrak
Tujuan penelitian ini untuk menguji pengaruh interaksi koneksi politik dengan GCG terhadap penghindaran pajak. Sampel dalam penelitian ini adalah seluruh perusahaan manufaktur di Bursa Efek Indonesia (BEI). Metode penentuan sampel menggunakan purposive sampling sesuai dengan kriteria yang telah ditentukan dan diperoleh sampel sebanyak 279. Teknik analisisnya adalah regresi linear berganda. Hasil pengujian analisis regresi linear berganda menunjukkan bahwa GCG tidak berpengaruh pada penghindaran pajak, sedangkan interaksi koneksi politik dengan Good Corporate Gavernance (GCG) berpengaruh signifikan pada penghindaran pajak, jadi Good Corporate Gavernance (GCG) yang diproksikan dengan dewan komisaris dan komite audit pure moderating sedang dewan direksi sebagai variabel semu atau quasi moderating. Penghindaran pajak merupakan usaha meringankan beban pajak dengan tidak melanggar undang-undang. Penghindaran pajak merupakan persoalan yang rumit dan unik karena tidak melanggar hukum (legal) namun tidak diinginkan oleh pemerintah karena mengurangi penerimaan negara
\end{abstract}

Kata Kunci: Good Corporate Governance, Koneksi Politik, Penghindaran Pajak 


\section{PENDAHULUAN}

Pajak menjadi salah satu sumber pendapatan negara yang paling penting karena memberikan kontribusi terbesar terhadap penerimaan negara. Pajak merupakan kontribusi wajib kepada negara yang terutang oleh wajib pajak bersifat memaksa berdasarkan Undang-Undang dengan tidak mendapat timbal balik secara langsung dan digunakan untuk keperluan negara bagi sebesar-besarnya kemakmuran rakyat (UU No.28 Tahun 2007 tentang Ketentuan Umum dan Tata Cara Perpajakan). Pengaruh pajak sebagai penerimaan terbesar pendapatan negara dapat dilihat dari data realisasi penerimaan negara pada tabel berikut:

Tabel 1 Penerimaan Pajak

\begin{tabular}{ccccc}
\hline Tahun & Penerimaan Pajak & Penerimaan Bukan Pajak & Hibah & Total \\
\hline 2014 & $1.146 .865,80$ & $398.590,50$ & $5.034,50$ & $1.550 .490,80$ \\
2015 & $1.240 .418,86$ & $255.628,48$ & $11.973,04$ & $1.508 .020,38$ \\
2016 & $1.284 .970,10$ & $261.976,30$ & $8.987,70$ & $1.555 .934,10$ \\
2017 & $1.472 .709,90$ & $260.242,10$ & $3.108,10$ & $1.736 .060,10$ \\
2018 & $1.618 .100,00$ & $270.400,00$ & $1.200,00$ & $1.889 .700,00$ \\
\hline
\end{tabular}

Sumber: https://www.bps.go.id

Tabel 1 menunjukkan bahwa penerimaan dari sektor pajak memberikan kontribusi paling besar dibandingkan sektor lainnya, sehingga penerimaan pajak bagi negara sangat dominan dalam menunjang jalannya roda pemerintahan dan terus mengalami peningkatan dari tahun ke tahun sebagai sumber penerimaan utama negara. Meskipun demikian, penerimaan pajak di Indonesia saat ini masih belum maksimal melihat rasio penerimaan pajak (tax ratio) di Indonesia saat ini berada di 10,7 \% dan menurun dari tahun ke tahun. Hal ini menunjukkan bahwa penerimaan pajak di Indonesia belum maksimal, padahal Indonesia memiliki potensi penerimaan pajak yang tinggi dikarenakan besarnya jumlah penduduk dan kegiatan usaha.

Sistem pemungutan pajak di Indonesia menggunakan self assesment system yang memberikan wewenang kepada wajib pajak untuk menghitung, melaporkan, dan membayarkan sendiri kepada pemerintah (Arianandini \& Ramantha, 2018; Ferdiawan \& Firmansyah, 2017). Dampak penetapan sistem pemungutan pajak ini akan memberikan celah kepada wajib pajak untuk melaporkan pajak yang lebih rendah dari seharusnya sehingga menyebabkan ketidakpatuhan yang dilakukan oleh wajib pajak yang akan berdampak pada upaya untuk melakukan penghindaran pajak (tax avoidance). Hal itu dilakukan untuk memaksimalkan keuntungan pemegang saham, mengurangi risiko pengawasan pajak, dan terkait dengan political cost (Butje \& Tjondro, 2014).

Fenomena tindakan penghindaran pajak (tax avoidance) oleh wajib pajak badan terjadi di Indonesia seperti PT Toyota Motor Manufacturing Indonesia (TMIIN) merupakan induk perusahaan dari Astra Internasional Tbk (ASII) dengan memanfaatkan transaksi antar-perusahaan terafiliasi di dalam dan luar negeri untuk menghindari pembayaran pajak 
menggunakan transfer pricing. Hal ini dilakukan untuk menghindari membayar pajak yang tinggi di Indonesia, yaitu dengan sengaja menjual produk tersebut ke Toyota Motor Asia Pasific Ltd di Singapura sebelum dijual ke Filipina dan Thailand dengan memanfaatkan tax heaven country di Singapura.

Penghindaran pajak (tax avoidance) merupakan usaha meringankan beban pajak dengan tidak melanggar undang-undang (Mardiasmo, 2016). Tekniknya dilakukan dengan memanfaatkan kelemahan-kelemahan dalam undang-undang dan peraturan perpajakan untuk memperkecil jumlah pajak yang terutang sehingga melakukan transaksi yang tidak dibebankan pada beban pajak. penelitihan tentang yang mempengaruhi kinerja perusahaan (Feng \& Johansson, 2018; Markonah, Cahaya, \& Riwayati, 2016; Wahyudin \& Solikhah, 2017; Zhou, Owusu-Ansah, \& Maggina, 2018) dan pinghindaran Pajak seperti coparate Governance, corporate Sosial Responsibility, kinerja Lingkungan, Polical Connection (Ferdiawan \& Firmansyah, 2017; Gray, Harymawan, \& Nowland, 2016; Muharam, 2012; Prasetyo, Suwarno, \& Suwandi, 2016; Ferdiawan \& Firmansyah, 2017).

Tata kelola perusahaan yang dikenal dengan Good Corporate Governance (GCG) merupakan sistem yang mengarahkan sebagai fungsi untuk mengendalikan perusahaan dan keseimbangan kewenangan serta pertanggungjawaban ke stakeholders (Markonah et al., 2016; Sabirin, 2020; Wulandari et al., 2018). Tata kelola perusahaan diharapkan dapat diterapkan secara maksimal disesuaikan dengan tujuan untuk mendapatkan nilai perusahaan sebagai kunci suksesnya. GCG sebagai wujud dari pertanggungjawaban kepada stakeholder dan pihak lain, dengan keterwakilan GCG dapat meminimalisir dalam penghindaran pajak. Pimpinan yang memiliki hubungan politik atau koneksi dengan pemerintah, pernah menjadi pejabat pemerintah, militer dan legislatif akan cenderung lebih agresif. Hasil penelitian bahwa koneksi politik memiliki dampak positif terhadap penghindaran pajak yang menyatakan bahwa rata-rata perusahaan menggunakan koneksi politiknya untuk mendapatkan pembayaran pajak yang lebih rendah. Hasil tersebut serupa dengan penelitian yang dilakukan (Ding, Zhang, \& Zhang, 2007; Luh \& Puspita, 2017; C. Zhang, 2017) juga menyatakan bahwa perusahaan yang memiliki koneksi politik cenderung melakukan penghindaran pajak daripada perusahaan yang tidak memiliki koneksi politik. Biaya politik memperkenalkan suatu dimensi politik pada pemilihan kebijakan akuntansi.

\section{METODE}

Pada penelitian ini digunakan analisis berganda menggunakan uji interaksi atau Moderated Regression Annaysis (MRA) merupakan aplikasi khusus regresi linier berganda dimana dalam persamaan regresinya mengandung unsur interaksi (Ghozali, 2009). Tujuan analisis ini yaitu untuk mengetahui apakah variabel moderating akan memperkuat atau memperlemah hubungan antara variabel independen dan variabel dependen yang diterapkan untuk menguji pengaruh variabel moderasi (koneksi politik) terhadap variabel independen (return on asset) dan variabel dependen (penghindaran pajak). Model persamaan regresi dapat di rumuskan sebagai berikut: 


\section{Pengujian Perumusan 1}

$\mathrm{ETR}=\alpha+\beta 1 \mathrm{CG}+\varepsilon$

\section{Pengujian Perumusan 2}

$\mathrm{ETR}=\alpha+\beta 1 \mathrm{CG}+\beta 2 \mathrm{Pc}+\varepsilon$

\section{Pengujian Perumusan 3}

$\mathrm{ETR}=\alpha+\beta 1 \mathrm{CG}+\beta 2 \mathrm{Pc}+\beta 3 \mathrm{CG}^{*} \mathrm{Pc}+\varepsilon$

\section{Keterangan:}

$\begin{array}{ll}\text { ETR } & : \text { Penghindaran Pajak } \\ \alpha & : \text { Konstanta } \\ \beta 1, \beta 2, \beta 3 & : \text { Koefisien regresi } \\ \text { CG } & : \text { Corparate Gavernance } \\ \text { PC } & : \text { Koneksi Politik } \\ \text { CG*PC }_{\varepsilon} & : \text { Interaksi antara CG dengan Koneksi Politik } \\ \varepsilon & : \text { Standar error }\end{array}$

Variabel perkalian CG*PC merupakan variabel moderating karena menggambarkan pengaruh moderating Xm terhadap X terhadap hubungan X dan Y. Sedangkan variabel Corporate Gavernance (dewan komisaris, komite audit dan dewan direksi) merupakan pengaruh langsung dari variabel $\mathrm{X}$ terhadap variabel $\mathrm{Y}$. Selain itu variabel moderasi mempunyai empat jenis moderasi, dapat dilihat pada tabel berikut:

Tabel 2 Uji Variabel Moderasi

\begin{tabular}{|c|c|c|}
\hline No. & Hasil Uji & Jenis Moderasi \\
\hline 1. & $\begin{array}{l}\beta_{2} \text { non significant } \\
\beta_{3} \text { significant }\end{array}$ & $\begin{array}{l}\text { Moderasi Murni (Pure Moderasi) } \\
\text { Artinya variabel yang memoderasi hubungan antara variabel prediktor } \\
\text { (independen) dan variabel dependen di mana variabel moderasi murni } \\
\text { berinteraksi dengan variabel prediktor tanpa menjadi variabel prediktor. }\end{array}$ \\
\hline 2 & $\begin{array}{l}\beta_{2} \text { significant } \\
\beta_{3} \text { significant }\end{array}$ & $\begin{array}{l}\text { Moderasi Semu (Quasi Moderasi) } \\
\text { Artinya variabel yang memoderasi hubungan antara variabel prediktor } \\
\text { (independen) dengan variabel dependen yang sekaligus menjadi variabel } \\
\text { independen. }\end{array}$ \\
\hline 3. & $\begin{array}{l}\beta_{2} \text { significant } \\
\beta_{3} \text { non significant }\end{array}$ & $\begin{array}{l}\text { Prediktor Moderasi (Predictor Moderasi Variabel) } \\
\text { Artinya variabel moderasi ini hanya berperanan sebagai variabel prediktor } \\
\text { (independen) dalam model hubungan yang dibentuk. }\end{array}$ \\
\hline 4. & $\begin{array}{l}\beta_{2} \text { non significant } \\
\beta_{3} \text { non significant }\end{array}$ & $\begin{array}{l}\text { Moderasi Potensial (Homologiser Moderasi) } \\
\text { Artinya variabel tersebut potensial menjadi variabel moderasi. }\end{array}$ \\
\hline
\end{tabular}

Sumber: Solimun, 2010 
Dalam penelitian kualitatif rawan sekali data yang diperoleh terjadi bias. Hal tersebut wajar adanya, karena yang dicari adalah kata-kata sehingga tidak mustahil terdapat katakata keliru yang tidak sesuai antara yang di katakan dengan keadaan yang sesungguhnya. Guna menjaga keabsahan data dalam penelitian, maka digunakan pemeriksaan keabsahan data sebagai berikut: (1) derajat kepercayaan (credibility), (2) keteralihan (transferability), (3) ketergantungan (dependability), dan (4) obyektivitas (confirmability).

\section{HASIL DAN PEMBAHASAN}

Penelitian ini menggunakan variabel independen yaitu GCG (Good Corporate Governance) yang diproksikan dengan dewan komisaris, komite audit, dewan direksi, variabel dependen yaitu penghindaran pajak yang diproksikan dengan effective tax ratio, serta variabel moderasi yaitu koneksi politik. Hasil uji statistik deskriptif dari masing-masing variabel dalam penelitian ini adalah sebagai berikut:

Tabel 3 Hasil Descriptive Statistics

\begin{tabular}{cccccc}
\hline & N & Minimum & Maximum & Mean & Std. Deviation \\
\hline ETR & 279 & .09 & .47 & .2498 & .05173 \\
PC & 279 & .00 & 1.00 & .4265 & .49546 \\
DK & 279 & 2.00 & 12.00 & 4.3154 & 1.95290 \\
KAu & 279 & 2.00 & 5.00 & 3.0789 & .30737 \\
DDir & 279 & 2.00 & 16.00 & 5.4516 & 2.42373 \\
PC_DK & 279 & .00 & 12.00 & 2.3907 & 3.08070 \\
PC_KAu & 279 & .00 & 5.00 & 1.3513 & 1.59312 \\
PC_DDir & 279 & .00 & 16.00 & 2.8100 & 3.78606 \\
\hline Valid N & 279 & & & \\
\hline
\end{tabular}

Sumber: Data diolah

Tabel 3 menunjukkan hasil uji statistik deskriptif untuk setiap variabel. Selanjutnya dilakukan penghapusan outlier dari hasil tersebut untuk variabel ETR (Effective Tax Ratio). Pengujian outlier disajikan dalam tabel sebagai berikut:

Tabel 4 Hasil Uji Outlier

\begin{tabular}{ccccc}
\hline Case Number & Std. Residual & ETR & Predicted Value & Residual \\
\hline 75 & -3.008 & .12 & .2487 & -.13069 \\
151 & -3.038 & .11 & .2400 & -.13197 \\
\hline
\end{tabular}

Sumber: Data diolah 
Sementara itu, hasil uji hipotesis dalam penelitian ini adalah sebagai berikut:

\section{Pengujian Perumusan 1}

Uji regresi pertama dilakukan untuk menguji Good Corporate Governance versus

Penghindaran Pajak. Berikut ini adalah hasil uji regresi yang terbentuk:

\section{ETR=0,258-0,003DK-0,002KAu+0,001}

\section{Pengujian Perumusan 2}

Uji regresi kedua dilakukan untuk menguji Good Corporate Governance dan Koneksi Politik versus Penghindaran Pajak. Berikut ini adalah hasil uji regresi yang terbentuk:

\section{ETR=0,251-0,009PC-0,002DK+8.837E-5KAu+0,002DDir}

\section{Pengujian Perumusan 3}

Uji regresi ketiga dilakukan untuk menguji Koneksi Politik memperkuat Good Corporate Governance terhadap Penghindaran Pajak. Berikut ini adalah hasil uji regresi yang terbentuk:

\section{ETR=0,010+0,284PC+0.005DK+0,075KAu+9.671E-5DDir-0,009PC*DK- 0,089PC*KAu+0,002PC*DDir}

Hasil pengujian Good Corporate Gavernance (GCG) yang diproksikan dengan dewan komisaris, komite audit dan dewan direksi terhadap penghindaran pajak menyimpulkan bahwa GCG tidak berpengaruh dengan arah berlawanan (negatif) terhadap Penghidaran pajak (effective tax ratio). Hal ini menunjukkan apabila GCG dalam suatu perusahaan meningkat, maka semakin kecil kemungkinan terjadinya praktik penghindaran pajak. Namun apabila semakin rendah GCG yang dimiliki oleh perusahaan, maka semakin besar terjadinya praktik penghindaran pajak. Kinerja GCG berpengaruh negatif dengan penghindaran pajak karena perusahaan dengan tingkat efisien yang tinggi dan memiliki pendapatan tinggi cenderung menghadapi beban pajak yang rendah.

Rendahnya beban pajak dikarenakan perusahaan dengan pendapatan yang tinggi berhasil mampu mengatur pendapatan dan pembayaran pajaknya. Hasil penelitian ini juga bersesuaian dan konsisten dengan penelitian yang mengatakan bahwa perusahaan yang memiliki laba besar akan cenderung membayar pajak, sedangkan perusahaan yang memiliki laba rendah akan cenderung menghindari pajak karena merasa akan mengalami kerugian jika harus membayar pajak juga. Serupa dengan hasil penelitian Arianandini \& Ramantha (2018) yang membuktikan kinerja perusahaan berpengaruh negatif terhadap penghindaran pajak hal ini dikarenakan semakin profitable perusahaan maka perusahaan tersebut dapat memposisikan diri dalam tax planning sehingga mampu memperoleh pajak yang optimal.

Hasil penelitian ini tidak sejalan (Darmawan \& Sukartha, 2014; Dewinta \& Setiawan, 2016) memberi hasil kinerja berpengaruh positif dan signifikan terhadap tax avoidance dimana mereka mengindikasikan bahwa perusahaan mampu mengelola asetnya dengan baik salah satunya dengan memanfaatkan beban penyusutan dan amortisasi, serta beban penelitian dan pengembangan yang dapat dimanfaatkan sebagai pengurang penghasilan kena 
pajaknya serta memperoleh keuntungan kelonggaran pajak lainnya sehingga perusahaan tersebut terlihat melakukan penghindaran pajak.

\section{Koneksi Politik memperkuat Good Corporate Gavernance terhadap Penghindaran Pajak}

Hasil pengujian koneksi politik pada pimpinan perusahaan (dewan direksi, dan dewan komisaris) yang memiliki hubungan politik dengan riwayat pekerjaan pernah menjabat sebagai pejabat pemerintahan memperkuat Good Corporate Gavernace terhadap penghindaran pajak dalam penelitian ini yang menyimpulkan bahwa interaksi koneksi politik dengan Good Corporate Gorvernance memperkuat dengan arah yang searah (positif) terhadap penghindaran pajak. Hal ini menunjukkan apabila hubungan politik yang dimiliki perusahaan dengan Good Corporate Gorvernance meningkat, maka semakin tinggi kecenderungan perusahaan melakukan praktik penghindaran pajak.

Jika dijelaskan dengan berpijak pada perspektif teori political cost hypothesis. Teori tersebut menjelaskan alasan perusahaan memilih kebijakan akuntansi untuk meminimalkan beban pajak penghasilan. Pajak penghasilan dianggap sebagai biaya politik sehingga perusahaan cenderung untuk melakukan tindakan oportunis dalam memilih kebijakan akuntansi untuk menurunkan taxable income. Sesuai dengan teori tersebut, perusahaan dapat meminimumkan biaya politis berupa beban pajak melalui koneksi politik yang dimiliki perusahaan melihat keberadaan para pejabat negara atau politisi partai dalam perusahaan akan menimbulkan hubungan yang menguntungkan. Berbagai macam hak-hak istimewa dapat diperoleh perusahaan dengan koneksi politik seperti kemudahan memperoleh pinjaman modal, memperoleh kontrak proyek dari pemerintah (Butje \& Tjondro, 2014; K. Zhang, 2016), rendahnya kemungkinan pemeriksaan dan pengurangan sanksi pajak, dan kemungkinan terlibat dalam aktivitas penghindaran pajak.

Koneksi politik yang dimiliki perusahaan memperkuat dengan arah yang searah (positif) dan signifikan dengan penghindaran pajak karena perusahaan yang memiliki koneksi politik akan mendapat perlindungan dari pemerintah, memperoleh akses pinjaman modal dengan mudah, dan resiko yang rendah saat pemeriksaan pajak. Hal ini membuat perusahaan menjadi fokus untuk memperoleh profit perusahaan. Sejalan dengan (Ding et al., 2007) bahwa ketika perusahaan dikendalikan oleh pemerintah dengan board chair terhubung politik memiliki pengaruh dan mampu meningkatkan kinerja perusahaan. (Ferdiawan \& Firmansyah, 2017) mengatakan bahwa perusahaan yang terkoneksi politik akan lebih dapat menikmati pendapatan lebih tinggi dan produktivitas lebih besar.

Hasil penelitian ini sejalan dengan penelitian yang dilakukan oleh (K. Zhang, 2016) yang hasilnya menunjukkan bahwa koneksi politik berpengaruh terhadap penghindaran pajak yang menyimpulkan bahwa koneksi politik yang dibangun perusahaan akan meningkatkan kemungkinan perusahaan terlibat dalam aktivitas penghindaran pajak. (Markonah et al., 2016; Suhartono, n.d.) juga menyatakan bahwa political connection meningkatkan kinerja perusahaan serta memperoleh keuntungan pajak. 
Untuk melihat interaksi moderating, terbentuk formula sebagai berikut:

\section{ETR=0,010+0,284PC+0.005DK+0,075KAu+9.671E-5DDir-0,009PC*DK- 0,089PC*KAu+0,002PC*DDir}

Dari persamaan tersebut, peneliti ingin melihat dengan persamaan turunan interaksi variabel political connection dengan GCG diproksikan dewan komisaris menjadi persamaan $\frac{y}{x 1}+0,005 \mathrm{DK}-0,009 \mathrm{PC} * \mathrm{DK}$ dan untuk menentukan titik potong terhadap sumbu X maka $\frac{y}{x 1}=0$ sehingga menjadi $\mathrm{DK}=0,005$ : $-0,009$; titik potong sumbu $\mathrm{X}$ $(-0.55556: 0)$. Untuk menentukan titik potong terhadap sumbu $Y$ maka $X=0 ; \frac{y}{x 1}=$ 0,005; titik potong sumbu Y (0,005: 0$)$. Sehingga gambar variabel moderasi dapat ditentukan sebagai berikut:

\section{Gambar 1 Interaksi Moderating Koneksi Politik*Dewan Komisaris}

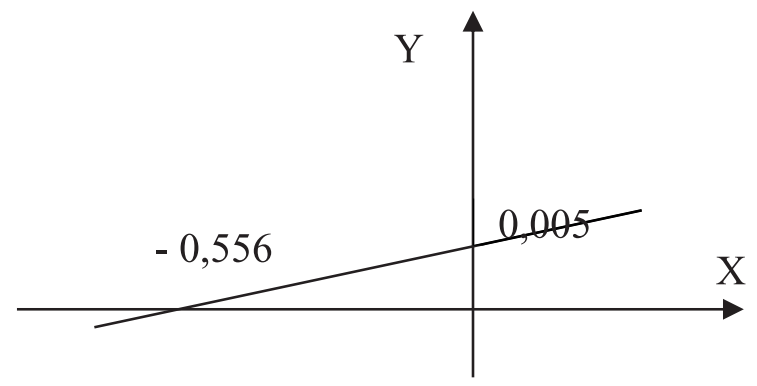

Gambar 1 menunjukkan bahwa political connection memperkuat hubungan GCG yang diprosikan dengan dewan komisaris terhadap penghindaran pajak, maka hubungan penghindaran pajak dan GCG proksi dewan komisaris tetap berpengaruh negatif. Jadi hasil penelitian political connection memperkuat GCG diproksikan dewan komisaris terhadap penghindaran pajak. Selain itu berdasarkan hasil uji regresi menunjukkan bahwa $\beta 2$ berpengaruh signifikan dan $\beta 5$ berpengaruh signifikan maka variabel koneksi politik ini merupakan variabel moderasi jenis moderasi semu (quasi moderating) yakni variabel moderasi yang memoderasi hubungan antara variabel independen dan variabel dependen yang juga sekaligus bisa menjadi variabel independen.

Selanjutnya peneliti ingin melihat dengan persamaan turunan interaksi variabel political connection dengan GCG diproksikan komite audit menjadi persamaan $\frac{y}{x 1}+0,075 \mathrm{KAu}$ $0,089 \mathrm{PC} * \mathrm{KAu}$ dan untuk menentukan titik potong terhadap sumbu X maka $\frac{y}{x 1}=0$ sehingga menjadi $\mathrm{KAu}=0,075$ : $-0,089$; titik potong sumbu $\mathrm{X}$ (-0.843: 0). Untuk menentukan titik potong terhadap sumbu Y maka $X=0 ;=0,075$; titik potong sumbu $Y(0,075$ : 0$)$. Sehingga gambar variabel moderasi dapat ditentukan sebagai berikut: 


\section{Gambar 2 Interaksi Moderating Koneksi Politik*Komite Audit}

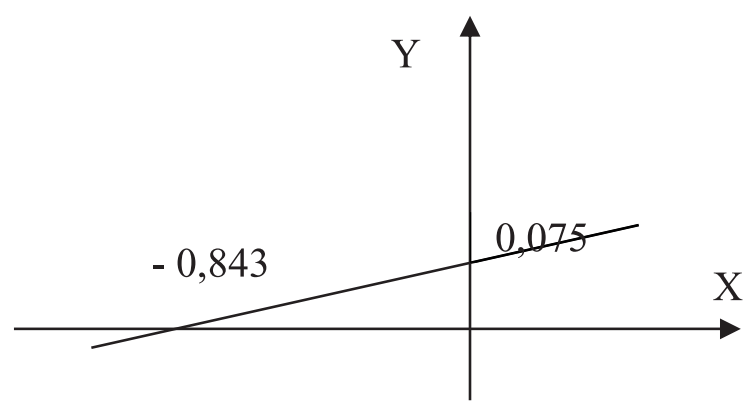

Gambar 2 menunjukkan bahwa political connection memperkuat hubungan GCG yang diprosikan dengan komite audit terhadap penghindaran pajak, meskipun di dalam hal ini political connection, maka hubungan penghindaran pajak (ETR) dan GCG proksi komite audit tetap berpengaruh negatif. Jadi hasil penelitian Political Connection memperkuat GCG diproksikan komite audit terhadap penghindaran pajak. Selain itu berdasarkan hasil uji regresi menunjukkan bahwa $\beta 3$ berpengaruh signifikan dan $\beta 6$ berpengaruh signifikan maka variabel koneksi politik ini merupakan variabel moderasi jenis moderasi semu (quasi moderating) yakni variabel moderasi yang memoderasi hubungan antara variabel independen dan variabel dependen yang juga sekaligus bisa menjadi variabel independen.

Selain itu peneliti juga ingin melihat dengan persamaan turunan interaksi variabel political connection dengan GCG diproksikan dewan direksi, didapat persamaan $\frac{y}{x 1}+$ 0,0000967 + 0,002PC*DDir dan untuk menentukan titik potong terhadap sumbu X maka $\frac{y}{x 1}=0$ sehingga menjadi DDir $=0,0000967$ : 0,002 ; titik potong sumbu $X(0,0844: 0)$. Untuk menentukan titik potong terhadap sumbu $Y$ maka $X=0 ; \frac{y}{x 1}=0,0000967$; titik potong sumbu Y (0,0000967: 0). Sehingga gambar variabel moderasi dapat ditentukan sebagai berikut:

Gambar 3 Interaksi Moderating Koneksi Politik dan Dewan Direksi

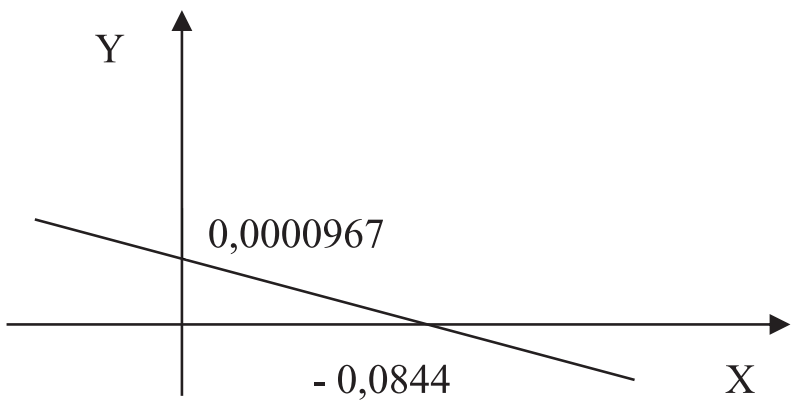

Gambar 3 menunjukkan bahwa political connection memperkuat hubungan GCG yang diproksikan dengan dewan direksi terhadap penghindaran pajak, meskipun didalam hal ini political connection, maka hubungan penghindaran pajak dan GCG proksi dewan direksi tetap tidak berpengaruh. Jadi hasil penelitian koneksi politik memperkuat proksi dewan 
direksi terhadap penghindaran pajak. Selain itu berdasarkan hasil uji regresi menunjukkan bahwa $\beta 4$ tidak berpengaruh dan $\beta 7$ tidak berpengaruh maka variabel koneksi politik ini merupakan variabel independen yakni variabel moderasi yang memoderasi hubungan antara variabel independen dan variabel dependen yang juga sekaligus bisa menjadi variabel independen.

\section{SIMPULAN}

GCG atau dikenal dengan tatakelola perusahaan memiliki pengaruh negatif dan signifikan terhadap penghindaran pajak. Hal ini menyimpulkan bahwa semakin banyak komposisi dewan komisaris, komite audit dan dewan direksi, maka semakin rendah perusahaan melakukan penghindaran pajak. Rendahnya beban pajak dikarenakan perusahaan dengan pendapatan yang tinggi mampu mengatur pendapatan dan pembayaran pajaknya. Interaksi koneksi politik dengan GCG memperkuat dengan arah yang searah (positif) dan signifikan terhadap penghindaran pajak. Hal ini menyimpulkan bahwa semakin tinggi hubungan politik yang dimiliki perusahaan akan meningkatkan GCG perusahaan untuk melakukan penghindaran pajak karena perusahaan yang memiliki koneksi politik akan mendapat kemudahan dari pemerintah, memperoleh akses pinjaman modal dengan mudah, dan resiko yang rendah saat pemeriksaan pajak sehingga membuat perusahaan menjadi fokus untuk memperoleh profit serta meningkatkan kemungkinan perusahaan terlibat dalam aktivitas penghindaran pajak.

Penelitian selanjutnya disarankan untuk menggunakan model variabel mediasi, variabel control untuk sampel untuk semua sektor dan menambahkan variabel lain seperti kualitas audit, kompensasi bonus, manajemen laba dan struktur kepemilikan.

\section{PUSTAKA ACUAN}

Arianandini, P. W., \& Ramantha, I. W. (2018). Pengaruh Profitabilitas, Leverage, dan Kepemilikan Institusional Pada Tax Avoidance. E-Jurnal Akuntansi, 22, 2088. https:// doi.org/10.24843/eja.2018.v22.i03.p17

Butje, S., \& Tjondro, E. (2014). Pengaruh Karakter Eksekutif dan Koneksi Politik Terhadap Tax Avoidance. Tax and Accounting Review, 4(2), 1-9.

Darmawan, I., \& Sukartha, I. (2014). Pengaruh Penerapan Corporate Governance, Leverage, Roa, Dan Ukuran Perusahaan Pada Penghindaran Pajak. E-Jurnal Akuntansi, 9(1), 143-161.

Dewinta, I. A. R., \& Setiawan, P. E. (2016). Pengaruh Ukuran Perusahaan, Umur Perusahaan, Profitabilitas, Leverage, Dan Pertumbuhan Penjualan Terhadap Tax Avoidance. E-Jurnal Akuntansi Universitas Udayana, 14(3), 1584-1613.

Ding, Y., Zhang, H., \& Zhang, J. (2007). Private vs state ownership and earnings management: Evidence from Chinese listed companies. Corporate Governance: An International Review, 15(2), 223-238. https://doi.org/10.1111/j.1467-8683.2007.00556.x

Feng, X., \& Johansson, A. C. (2018). Living through the Great Chinese Famine: Early-life 
experiences and managerial decisions. Journal of Corporate Finance, 48, 638-657. https://doi.org/10.1016/j.jcorpfin.2017.11.012

Ferdiawan, Y., \& Firmansyah, A. (2017). Pengaruh Political Connection, Foreign Activity, dan Real Earnings Management Terhadap Tax Avoidance Pendapatan Perpajakan merupakan. Jurnal Akuntansi Dan Keuangan, 5(3), 1601-1624.

Gray, S., Harymawan, I., \& Nowland, J. (2016). Political and government connections on corporate boards in Australia: Good for business? Australian Journal of Management, 41(1), 3-26. https://doi.org/10.1177/0312896214535788

Luh, N., \& Puspita, P. (2017). Pengaruh Ukuran Perusahaan, Leverage, Profitabilitas dan Corporate Social Responsibility Terhadap Penghindaran Pajak (Tax Avoidance). E-Jurnal Akuntansi, 21, 882-911. https://doi.org/10.24843/EJA.2017.v21.i02.p01

Markonah, Cahaya, Y. F., \& Riwayati, H. E. (2016). The Effect of Banking Company Performance toward Good Corporate Governance Listed in Indonesia Stock Exchange. Procedia - Social and Behavioral Sciences, 219, 486-492. https://doi.org/10.1016/j. sbspro.2016.05.024

Muharam, H. (2012). Analisis Pengaruh Harga Miny Ak Dan Harga Emas Terhadap Hubungan Timbal-Balik Kurs Dan Indeks Harga Saham Gabungan (Lhsg) Di Bursa Efek Indonesia (BEl) 2000 -2013. Jurnal Bisnis Strategi, 21(1). https://doi.org/10.14710/ jbs.21.1.72-94

Prasetyo, Suwarno, \& Suwandi. (2016). Pengaruh Kinerja Lingkungan Dan Kinerja Komite Audit Terhadap Kinerja Ekonomi Perusahaan, 1(1), 49-63.

Sabirin, S. (2020). Kinerja Keuangan Bank Syariah Mandiri: Sebelum dan Sesudah Penerapan Good Corporate Governance. Akuntabilitas, 13(1), 51-62. https://doi.org/10.15408/ akt.v13i1.12259

Suhartono, P. A. (n.d.). Pengaruh Political Connection Dewan Direksi Dan Dewan Komisaris Terhadap Return On Equity Dan Asset Turnover Perusahaan Di Sektor Konstruksi, 261-270.

Suwandi, S., Sukaris, S., \& Faris, A. (2019). Model CSR dalam Penguatan Modal Sosial dan Peran Kelembagaan Masyarakat. Akuntabilitas, 12(1), 105-118. https://doi.org/10.15408/ akt.v12i1.12748

Wahyudin, A., \& Solikhah, B. (2017). Corporate governance implementation rating in Indonesia and its effects on financial performance. Corporate Governance: The International Journal of Business in Society, 17(2), 250-265. https://doi.org/10.1108/ CG-02-2016-0034

Wulandari, R., Tumirin, T., \& Suwandi, S. (2018). Good Corporate Governance dan Kinerja Non Keuangan. JIATAX (Journal of Islamic Accounting and Tax), 1(2), 160. https://doi. org/10.30587/jiatax.v1i2.1019

Zhang, C. (2017). Political connections and corporate environmental responsibility: Adopting or escaping? Energy Economics, 68, 539-547. https://doi.org/10.1016/j. eneco.2017.10.036 
Zhang, K. (2016). Discussion of "Corporate Political Connections and Tax Aggressiveness." Contemporary Accounting Research, 33(1), 115-120. https://doi.org/10.1111/19113846.12214

Zhou, H., Owusu-Ansah, S., \& Maggina, A. (2018). Board of directors, audit committee, and firm performance: Evidence from Greece. Journal of International Accounting, Auditing and Taxation, 31(March), 20-36. https://doi.org/10.1016/j.intaccaudtax.2018.03.002 